\title{
THE HYPOGLYCAEMIC SULPHONYLUREAS
}

\author{
By G. Walker, B.Sc., M.B., M.R.C.P.* \\ From the Institute of Clinical Research, Middlesex Hospital Medical School
}

Recent reports in the medical and lay press of drugs which lower the blood sugar when given by mouth have attracted much attention and many diabetics have already asked their clinic physicians or family practitioners for information. The interest in, and the importance of, the drugs is such that entire issues of the British Medical Fournal, the Canadian Medical Association Fournal and Metabolism have been devoted to symposia on them, but, despite a great deal of investigation, their mode of action remains unknown and their place in the treatment of diabetes uncertain.

\section{The Initial Observations}

In 1942 Janbon, working in Montpellier, had to abandon a trial of a sulphonamide, p-aminobenzenesulphonamido iso - propylthiodiazole (IPTD) in typhoid fever patients because he found that it caused severe, and in some instances fatal, hypoglycaemia. Loubatières quickly demonstrated a hypoglycaemic effect in intact and partially pancreatectomized, but not in totally pancreatectomized, dogs, but interest lapsed until 1954, when he started trials in diabetics.

In 1955 Franke and Fuchs found that another sulphonamide, I-butyl 3-sulphanilyl urea (carbutamide), also being tried for its antibacterial activity, caused hypoglycaemia; this and the closely related drug, I-butyl 3p-tolylsulphonyl urea (tolbutamide), have been extensively investigated and are discussed in this paper.

\section{Pharmacology}

Carbutamide (B.Z. 55. U.6987. Nadisan, Invenol) is I-butyl 3-sulphanilyl urea and has the formula:

$$
\mathrm{NH}_{2} \backslash \mathrm{SO}_{2} \cdot \mathrm{NH} \cdot \mathrm{CO} \cdot \mathrm{NH} \cdot \mathrm{C}_{4} \mathrm{H}_{9}
$$

It is rapidly absorbed when given by mouth and may be estimated by the Bratton Marshall method for sulphonamides. It is distributed throughout the extracellular fluid space and plasma

\footnotetext{
* Leverhulme Research Scholar.
}

and serum levels are about 40 per cent. higher than those of whole blood. In man maintenance doses of 2 to $3 \mathrm{~g}$. daily give blood levels between ro and $20 \mathrm{mg}$./100 ml. and the hypoglycaemic effect in responsive individuals is roughly proportional to the blood level. The drug is excreted in the urine in the free and acetylated forms, both of which are sufficiently soluble to preclude the danger of crystalluria. Excretion is slow and significant blood levels (of the order of $\mathrm{I} . \mathrm{mg} . / 100 \mathrm{ml}$.) are found as long as a week after stopping treatment.

Tolbutamide (D.86o. U.2043. Orinase.) is I-butyl 3p-tolylsulphonyl urea and has the formula :<smiles>CCCCCNC(=O)NOS(=O)(=O)c1ccccc1</smiles>

It cannot be estimated by the Bratton Marshall method, as it lacks a p-amino group, but may be measured spectrophotometrically in chloroform extracts. Absorption from the gut is rapid and in man single doses of $100 \mathrm{mg}$. $/ \mathrm{kg}$. give plasma levels of 12 to $43 \mathrm{mg}$./ $100 \mathrm{ml}$. at 2 hours. Excretion is more rapid than with carbutamide and the blood level falls to about 15 per cent. of the peak value 24 hours after a single oral dose (Mortimore et al.). The drug is excreted in the urine chiefly as an oxidation product, i-butyl 3-carboxyphenylsulphonyl urea (Forist and Chulski), which has no hypoglycaemic action. There is no danger of crystalluria, but extreme acidification of the urine of patients taking the drug, as in the salicylsulphonic acid test for protein, may produce a white precipitate. The dose-response relationship is less close than with carbutamide, possibly because of greater fluctuations in blood levels, but for practical purposes the drugs are equally potent (McGavack et al.).

Carbutamide and tolbutamide are at present available in the United Kingdom only for clinical trial and are issued in $\frac{1}{2}-\mathrm{g}$. tablets.

\section{Mode of Action}

As there is nothing to suggest that carbutamide and tolbutamide differ in their mode of action, 
they will be discussed together. Carbutamide was at first more widely available, so most of the early observations were made with it.

\section{Basic Observations}

I. The drugs cannot act without insulin. It is generally agreed that carbutamide and tolbutamide reduce the fasting blood sugar in intact and partially pancreatectomized animals and in animals made mildly diabetic with small doses of alloxan, but that they are ineffective after total pancreatectomy (Houssay and Penhos) and in animals made severely diabetic with large doses of alloxan (Lang and Sherry). Similarly, they are inactive in totally pancreatectomized humans (Fajans et al.) and are often effective in patients with clinically mild diabetes, i.e. those in whom the disorder has usually appeared in later adult life, who do not become ketotic without insulin treatment and who are frequently overweight, at least at the onset. Patients of this type have appreciable amounts of insulin in their plasma (Bornstein and Lawrence) and pancreas (Wrenshall and Best) and are often controlled without insulin. In contrast, the drugs are generally ineffective in patients with clinically severe diabetes, in whom the disorder has often appeared early in life, who readily become ketotic without insulin treatment, whose presenting symptoms, including loss of weight, are severe, and whose plasma and pancreas contain virtually no insulin.

It seems, therefore, that, as the sulphonylureas cannot act without insulin, they are not true insulin substitutes.

2. The effects of the drugs differ from those of insulin. Most workers agree that, unlike insulin, carbutamide and tolbutamide do not reduce the rise of blood sugar which follows a carbohydratecontaining meal. Purnell et al. also claim that tolbutamide given by mouth, and in doses of $1.5 \mathrm{~g}$. by intravenous injection, does not increase peripheral glucose utilization, as shown by its lack of effect on capillary-venous blood sugar differences and on the plasma potassium and phosphate levels (which usually fall after the administration of carbohydrate and insulin). Goetz et al., however, claim to have produced a significant increase in capillary-venous blood sugar differences and a fall of plasma potassium and phosphate in normal subjects given tolbutamide, $50 \mathrm{mg}$./kg., by intravenous injection. The dose used was twice that used by Purnell et al. and, although not measured, the blood levels must have been very much higher than those achieved in patients taking maintenance doses of the drug by mouth.

Four major hypotheses have been suggested to explain the action of the sulphonylureas:
I. Stimulation of insulin production was first suggested by Loubatières to explain the lack of effect of IPTD in pancreatectomized and severely alloxan diabetic animals. Supporting evidence has been published by Colwell et al., who found that hypoglycaemia could be induced in dogs by the injection of carbutamide and tolbutamide into the pancreatic artery in doses which were too small to produce an effect when injected into the portal vein or a femoral artery; and by Ashworth et al., who found that relatively large doses (I g./kg./day) of carbutamide given orally for three to five weeks caused islet cell hypertrophy in rats. The hypothesis cannot explain the inability of the drugs to produce all the effects characteristic of insulin and it may be argued that in mild diabetics the $\beta$ cells are working to capacity and that it is unlikely that they could be stimulated to produce more insulin.

2. Decreased destruction of insulin has been suggested by Mirsky et al., who demonstrated that carbutamide and tolbutamide reduced the in vitro insulinase activity of rat liver. Williams and Tucker have shown that the drugs slow the degradation of ${ }^{131}$ I labelled insulin in intact rats and in their livers studied in vitro. In both of these experiments effects were only obtained with concentrations of the drugs very much higher than necessary to produce profound effects in intact animals. Further objections are that the drugs do not produce exactly the same effects as insulin in partially depancreatectomized animals and in mild diabetics and that they usually cannot reduce the insulin requirements of patients with severe diabetes, occurring spontaneously or after pancreatectomy.

3. Inhibition of insulin antagonists was suggested by the observation of von Holt et al. that large doses of IPTD caused degeneration of the glucagon-secreting $\alpha$ cells in rabbits. Most American workers have, however, been unable to reproduce these findings with carbutamide and tolbutamide (Volk et al.). The hyperglycaemic effect of injected glucagon is unaltered in rabbits (Berthet $e t \cdot a l$.) and in man (Fajans et al.), so there cannot be a direct antagonism. Finally, the drugs are ineffective in alloxan diabetic animals where the $\alpha$ cells are known to be intact.

Inhibition of other hyperglycaemia-producing hormones has been excluded by Fajans et al., who have shown that the adrenal glucocorticoid excretion is unaffected and have studied patients with Addison's disease and panhypopituitarism who have responded both before and after hydrocortisone and fluorohydrocortisone replacement therapy. In addition, they were unable to detecit any effect on the hyperglycaemic response to adrenaline injection in man.

4. Decreased hepatic glucose output could explain 
Beringer's early observation that the drugs increase liver glycogen and why they reduce the fasting blood sugar, but not the post-prandial peak. Renold et al. found that, although fructose and glactose tolerance were unchanged in man, the drugs abolished the rise in blood glucose after the administration of these other sugars, which further supports the hypothesis of decreased glucogenesis. Purnell et al. obtained more direct evidence on this point: they cannulated the portal and hepatic veins of dogs and found that the hepatic glucose output fell after an intravenous injection of tolbutamide, whilst Berthet et al. found that the drug decreased the glucose output of rabbit liver slices, but only in concentrations very much higher than required to produce severe hypoglycaemia in intact animals.

The ultimate effect of the sulphonylureas is probably the inhibition of an hepatic glucogenic enzyme system. Ashmore et al. showed that both carbutamide and tolbutamide inhibited the glucose6-phosphatase activity of rat liver slices, but only in very high concentrations.

The normal shape of the glucose tolerance curve in treated patients and the direct observations made on rats by Friedlich et al. eliminate the admittedly unlikely possibility that the drugs act by interfering with glucose absorption.

\section{Clinical Experience and Indications}

The early reports from Germany (Bertram et al.) stressed, and it was soon amply confirmed, that only mild diabetics (as defined above), especially those in whom the disease is of relatively recent onset, - are to be expected to benefit from the sulphonylureas. It is usually possible to predict the response of an individual on clinical grounds alone, but objective tests have been devised in which the effect on the blood sugar of a single large dose of the drug to be tried therapeutically is studied. Thus Camerini-Davalos et al. gave $3 \mathrm{~g}$. of tolbutamide by mouth and showed that, of 15 patients who showed a fall in the fasting blood sugar of more than $20 \mathrm{mg}$. per cent. after 4 hours, II were satisfactorily maintained on $3 \mathrm{~g}$. of the drug daily, and Braverman et al., who injected I g. of tolbutamide intravenously, found a mean fall in the blood sugar of 26 per cent. in diabetics who were satisfactorily controlled by the drug and of 7 per cent. in those who did not respond to it. As an indirect measurement of neo-glucogenesis, Duncan et al. measured the urinary nitrogen excretion and found a reduction in patients who responded to carbutamide.

It must be stressed that the two most important factors in the treatment of mild diabetes are carbohydrate restriction and in obese patients, weight reduction, both of which are achieved only by strict dieting. The sulphonylureas should be reserved for those mild diabetics who are not overweight and whose hyperglycaemia cannot be adequately controlled by diet alone. Many such patients will have been treated with insulin and before changing to oral treatment this should be withdrawn by gradually reducing the dose over several days. It is important that they should be seen frequently, because in some patients initially considered suitable, the diabetes becomes dangerously uncontrolled and insulin treatment has to be resumed.

It is generally agreed that giving the sulphonylureas with insulin does not improve the control of labile or ' brittle' diabetes.

Wolff et al. were unable to correlate the clinical response with the proportion of free and acetylated carbutamide excreted in the urine.

\section{Dosage}

Carbutamide has usually been given in doses of $2 \frac{1}{2} \mathrm{~g}$. on the first day, $1 \frac{1}{2} \mathrm{~g}$. on the second day and then I to $3 \mathrm{~g}$. daily, as judged by the effect on blood and urine sugar concentrations. A single daily dose is, for practical purposes, as effective as several small doses. Tolbutamide has usually been given in daily doses of $\mathrm{I}$ to $4 \mathrm{~g}$. Because it is excreted rapidly, a loading dose is unnecessary and it must be given every 6 or 8 hours.

\section{Toxicity}

Both carbutamide and tolbutamide may cause mild, non-specific symptoms, such as malaise, fever and headache, when treatment is started, but these usually disappear within a few days. Carbutamide is a substituted p-amino benzene sulphonamide and it was to be expected that it would have some of the side effects of related drugs used for their antibacterial activity. 'Sulphonamide' rashes have been seen in about ro per cent. of treated patients, but the danger of the drug is from neutropenia, agranulocytosis and thrombocytopenia. The blood changes are reviewed by Phemister, who considers that the thrombocytopenia is a hypersensitivity reaction, mediated at least partly by an increased rate of platelet destruction. He has also suggested that carbutamide increases capillary fragility. Fulmer et al. have reported a single case of mild granulocytopenia due to tolbutamide, but so far thrombocytopenia has not been described.

Carbutamide and, to a much less extent, tolbutamide reduce the thyroid radio-iodine uptake and serum protein-bound iodine (Brown and Solomon) and carbutamide has caused clinical hypothyroidism (Walker et al.). 


\section{Dangers of Sulphonylurea Treatment}

The uncritical and uncontrolled use of the sulphonylureas, even in responsive patients, is dangerous. Apart from inherent toxicity,"especially with carbutamide, there may be excessive gain of weight with its attendant dangers, and it may not be appreciated that the drugs sometimes fail to prevent serious hyperglycaemia developing, especially during an acute infection, when insulin treatment will be necessary. Although there is as yet no evidence in man of impairment of liver function, the drug seems to act on liver enzymes and it is possible that long-term treatment will damage the liver. Phemister's observation that carbutamide (the only drug he investigated) increases capillary fragility suggests that the development of retinopathy and nephropathy, both essentially vascular disorders, may be accelerated. It is at present far too early to know whether the incidence of ' degenerative' complications (retinopathy, cataracts, arterial disease, neuropathy, diabetic nephropathy) in patients whose blood sugar has been adequately controlled with the sulphonylureas will differ from that in similar patients treated with insulin.

The danger of agranulocytosis and thrombocytopenia is such that carbutamide should never be used therapeutically. Tolbutamide appears to be safe, but, because its mode of action and long-term toxicity are unknown, should be used only in patients in whom frequent and detailed observation is possible.

\section{BIBLIOGRAPHY}

ASHMORE, J., CAHILL, G. F., and HASTINGS, A. B. (1956), Metabolism, 5, 774.

ASHWORTH, M. A., and HAIST, R. E. (1956), Canad. med. Ass. F., $74,975$.
BERTHET, J, SUTHERLAND, E. W, and MAKMAN, M. H. (I956), Metabolism, 5, 768 .

BERTRAM, F., BENDFELDT, E., and OTTO, H. (1955), Dtsch. med. Wschr., 80, 1452.

BORNSTEIN, J., and LAWRENCE, R. D. (195I), Brit. med. .., i, 732.

BRAVERMAN, A. E., DREY, N. W., and SHERRY, S. (1956), Metabolism, 5, $91 \mathrm{I}$.

BROWN, J., and SOLOMON, D. H. (1956), Metabolism, 5, 813.

CAMERINI-DAVALOS, R., MARBLE, A., and ROOT, H. W. (1956), Metabolism, 5, 904:

COLWELL, A. R., COLWELL, J. A., and COLWELL, A. R. (senior) (1956), Metabolism, 5, 749.

DUNCAN, L. J. P., BAIRD, J. D., and DUNLOP, D. M. (1956), Brit. med. F., ii, 433.

FAJANS, S. S., LOUIS, L. H., SELTZER, H. S., GITTLER, R. D., HENNES, A. R., WẢJCHENBERG, B.'L., ACKERMAN, I. P., and CONN, J. W. (1956), Metabolism, 5, 820 .

FORIST, A. A., and GHULSKI, T. (1956), Metabolism, 5, 807.

FRANKE, H., and FUCHS, J. (1955), Dtsch. med. Wschr., 80, 1449.

FRIEDLICH, T. L., ASHWORTH, M. A., HAWKINS, R. D., and HAIST, R. E. (1956), Canad. med. Ass. F., 74, 973.

FULMER, H. S., DUBE, A. H., and LLOYD, C. W. (1956), Metabolism, 5,940 .

GOETZ, F. C., GILBERTSEN, A. S., and JOSEPHSON, V. (1956), Metabolism, 5, 788.

HOLT, C. voN, HOLT, L. vON, KRONER, B., and KUHNAU, J. (1954), Naturwissenschaften, 4I, 166.

HOUSSAY, B. A., and PENHOS, J. C. (1956), Metabolism, 5, 727.

JANBON, M., LAZERGES, P., and METROPOLITANSKI, J. H. (1942), Montpellier méd., 22, 489.

LANG, S., and SHERRY, S. (1956), Metabolism, 5, 733.

LOUBATIERES, A. (1955), Méd. et Hyg. (Geneve), 13, 495.

MCGAVACK, T. H., SEEGERS, W., HAAR, H., and ERK, V. (1956), Metabolism, 5, 919.

MIRSKY, I. A., PERISUTTI, G., and DIENGOTT, D. (1956), Metabolism, 5, r56.

MORTIMORE, G. E., DIRAIMONDO, V. C., and FORSHAM, P. H. (1956), Metabolism, 5, 840.

PHEMISTER, J. C. (1957), Brit. med. f., i, 199.

PURNELL, R., ARAI, Y., PRATT, E., HLAD, C., and ELACK, H. (1956), Metabolism, 5, 778 .

RENOLD A. E., WINEGRAD, A. I.; FROESCH, E. R., and THORN, G. W. (1956), Metabolism, 5, 757.

VOLK, B. W., WEISENFELD, S., LAZARUS, S. S., and GÓLDNER, M. G. (1956), Metabolism, 5, 894.

WALKER, G., LEESE, W. L. B., and NABARRO, J. D. N. (1956), Brit. med. Ғ., ii, $45 \mathrm{I}$.

WILLIAMS, R. H., and TUCKER, B. W. (1956), Metabolism, 5,801 .

WOLFF F. W., STEWART, G. A., CROWLEY, M. F., and BLOOM, A. (1956), Brit. med. $f .$, ii, 440.

WRENSHALL, G. A., and BEST, C. H. (1956), Canad. med. Ass. F., 74, 968.

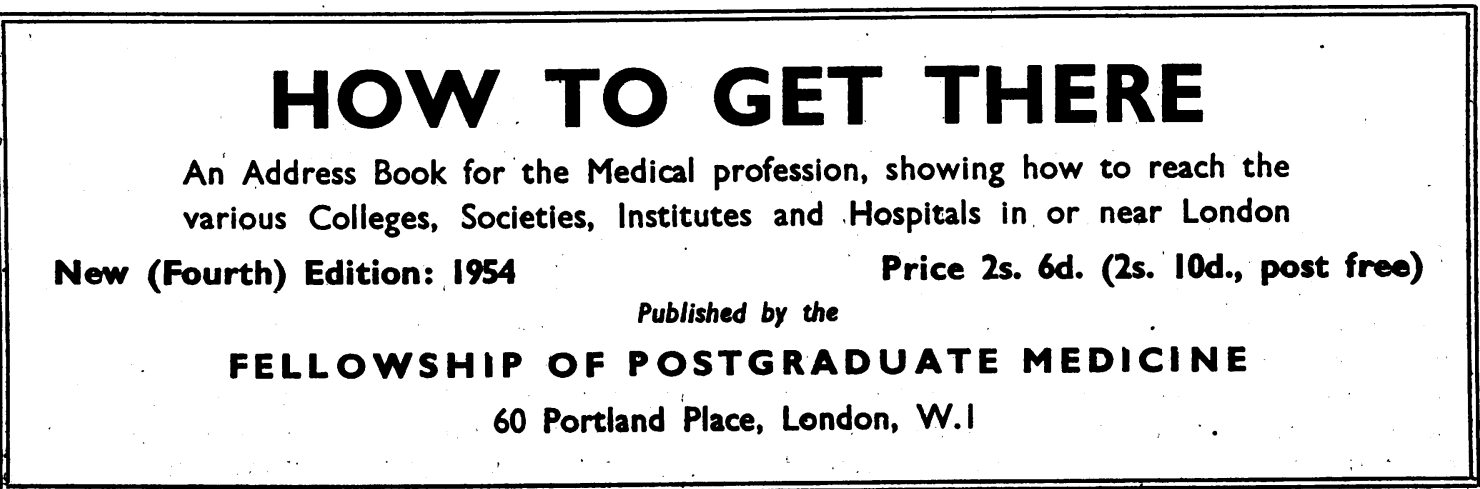

\section{HOW TO GET THERE}

An Address Book for the Medical profession, showing how to reach the

Published by the

Price 2s. 6d. (2s. 10d., post free) 